\title{
Inventory of Greenhouse Gases Emissions from Gasoline and Diesel Consumption in Nigeria
}

\author{
S. O. Giwa*, M. A. Sulaiman, C. N. Nwaokocha \\ Department of Agricultural and Mechanical Engineering, College of Engineering and Environmental Studies, \\ Olabisi Onabanjo University, Ibogun Campus, P.M.B. 5026, Ifo, Ogun State, Nigeria.
}

\begin{abstract}
Emissions from fossil fuel combustion are of global concern due to their negative effects on public health and environment. This paper is an inventory of the greenhouse gases (GHGs) released into the environment through consumption of fuels (gasoline and diesel) in Nigeria from 1980 to 2014. The fuel consumption data for the period in view were sourced from bulletins released by Nigeria National Petroleum Corporation, (NNPC) and were utilized for GHGs estimation based on default emission factors $\left(69300 \mathrm{~kg} / \mathrm{TJ}\left(\mathrm{CO}_{2}\right.\right.$; gasoline $), 74100 \mathrm{~kg} / \mathrm{TJ}\left(\mathrm{CO}_{2}\right.$; diesel), $18 \mathrm{~kg} / \mathrm{TJ}\left(\mathrm{CH}_{4}\right.$; gasoline), $3.85 \mathrm{~kg} / \mathrm{TJ}\left(\mathrm{CH}_{4}\right.$; diesel), $1.9 \mathrm{~kg} / \mathrm{TJ}\left(\mathrm{N}_{2} \mathrm{O}\right.$; gasoline $)$ and $2.25 \mathrm{~kg} / \mathrm{TJ}\left(\mathrm{N}_{2} \mathrm{O}\right.$; diesel $)$. In addition, the uncertainty and sensitivity analyses associated with the inventory were carried out. Total amount of GHGs emitted into the environment for the period under consideration was $7.30 \times 10^{8} \mathrm{tCO}_{2 \mathrm{e}}\left(5.20 \times 10^{8} \mathrm{tCO}_{2 \mathrm{e}}\right.$ and $2.10 \times 10^{8} \mathrm{tCO}_{2}$ e of gasoline and diesel, respectively). It is worth noting that gasoline consumption accounted for $71.23 \%$ of the total amount of GHGs with $\mathrm{CO}_{2}$ making up $98.72 \%\left(\mathrm{CH}_{4}=1.39 \%\right.$ and $\left.\mathrm{N}_{2} \mathrm{O}=0.61 \%\right)$ of the emissions. For this study, uncertainty of estimate was between $-80.93 \%$ and $78.36 \%$ while volume of diesel is more sensitive than the volume of gasoline of the input parameters. National policy and enforcement on low or neutral emission fuels utilization are amongst the recommended actions toward reducing GHG emissions in the country.
\end{abstract}

KEYWORDS: Emissions; inventory; petroleum products; greenhouse gases; carbon dioxide.

[Received May 24 2016; Revised April 13 2017; Accepted June 1 2017]

\section{INTRODUCTION}

Man-made emissions of greenhouse gases (GHGs) have increased by $70 \%$ ( 29 Gtons of $\mathrm{CO}_{2}$ equivalent $\left(\mathrm{tCO}_{2} \mathrm{e}\right)$ in 1970 to $49 \mathrm{GtCO}_{2}$ e in 2004), of which 25.8 Gtons came from $\mathrm{CO}_{2}$ emissions from the combustion of fossil fuels (OCED/ITF, 2009). In the developing world, automotive air pollution is mostly a problem in large cities with high levels of traffic, such as Mexico City, Bangkok, New Delhi and Lagos (Nigeria). In other cities, power plants, factories, and other stationary sources still constitute the greatest threat to air quality. However, the share of emissions from developing countries is expected to rise in the future because of the growing sizes of motor vehicle fleets and the use of less efficient fuel-burning technologies (IPCC, 1995).

One of the most important human impacts on the environment is the rapid increase in greenhouse gas (GHG) which includes carbon dioxide $\left(\mathrm{CO}_{2}\right)$, methane $\left(\mathrm{CH}_{4}\right)$, nitrous oxide $\left(\mathrm{N}_{2} \mathrm{O}\right)$, chlorofluorocarbons (CFCs), perfluorocarbons (PFCs), and hydrocarbons (HFCs) (Giwa, 2014). Levels of these gases are increasing as a direct result of human activity. Apart from global warming, GHGs are also responsible for the phenomenon known as ozone layer depletion. The rise in GHG is more rapid than at any time in the past because of the increase in industrial activities (Houghton et al., 2001). Emission of GHGs is due to an increased dependence on

*Corresponding author's e-mail address: sologiwa2002@yahoo.com machines and equipment that burn fossil fuels; such as automobiles and generators, as well as enhanced chemical processes carried out in factories and power plants. Another source is fire, from firewood cooking, bush burning, and incineration of refuse. Emission of $\mathrm{CO}_{2}$ is largely due to human activities; transportation, industry, and power plants and its release into the atmosphere can result in increase in ambient temperature, and consequent climatic changes (OCED/ITF, 2009).

The negative impact of GHGs on agriculture and food security, especially in tropical and subtropical regions is expected to increase the risk of hunger by additional 80 million people by 2080 in Africa and Southern Asia (Odjugo et al., 2001). Odjugo (2009) revealed that GHGs which caused climate change have led to a shift in crops cultivated in Northern Nigeria. The study reported that as at 1978, the preferred crops the farmers cultivated were guinea corn followed by groundnut and maize, but due to increasing temperature and decreasing rainfall amount and duration occasioned by climate change, the farmers as a means of adaptation in 2007 shifted to the production of millet followed by maize and beans. Another major problem to agriculture in Nigeria due to climate change is the reduction of arable lands. As the sea incursion is reducing the arable land of the coastal plains, the desert encroachment is depriving farmers of their grazing rangelands and agricultural

doi: http://dx.doi.org/10.4314/njtd.v14i1.1 
farmlands (Odjugo et al., 2003). Moreover, the frequent droughts and lesser rains have started shortening the growing season thereby causing crops' failure and food shortage.

The Intergovernmental Panel on Climate Change (IPCC) has developed a set of common guidelines for national GHG inventories by sources and sinks in relation to national obligations under the United Nation Framework Committee on Climate Change (UNFCCC). The GHG emissions inventory is an accounting of the amount of GHGs emitted to or removed from the atmosphere over a period of time. It also provides information on the activities that cause emissions and removals, as well as background on the methods used to make the calculations. Researchers use GHG inventories as inputs to atmospheric and economic models (Aderogba, 2011). Policy makers use GHG inventories to track emission trends, develop strategies and policies and assess progress (Aderogba, 2011). The total GHG emissions in Nigeria increased in 2000 to $135 \%$ of that in 1990, implying considerable increase in the socioeconomic activities (National Communication on Climate Change, 2014). Energy-related activities have the major share of emissions.

The energy sector recorded emissions of $155.34 \mathrm{MtCO}_{2}$ e, representing $70.4 \%$ of the country's total emission in 2000 with $\mathrm{CO}_{2}$ as the largest contributor (114.72 $\mathrm{MtCO}_{2}$ e) (National Communication on Climate Change, 2014). It is worth noting that the diesel or gasoline-powered electricity generator sets currently in monumental use in Nigeria, is an addition to national sources of GHGs emission and this has contributed significantly to the choking air in cities like Abuja and Lagos, which are beleaguered by smog shrouding the skyline of the central cities (Ndoke and Jimoh, 2005).

This study aimed at providing an inventory of the emission of GHGs released into the atmosphere through the combustion of fossil fuels (gasoline and diesel) made available for consumption over a period of 35 years (1980 2014). It involved the estimation of the amounts of $\mathrm{CO}_{2}, \mathrm{CH}_{4}$ and $\mathrm{N}_{2} \mathrm{O}$ and total GHGs emitted through the combustion of gasoline and diesel in Nigeria with the view of proffering possible solutions to reducing the GHGs which are devastating to the environment and human health.

\section{DATA ANAYLSIS}

\section{A. Emission estimation method}

The Tier 1 (sectoral) approach was employed in this study for the estimation of GHGs from the consumption of fuels (gasoline and diesel) according to the 2006 guidelines on National GHG Inventories (IPCC, 2006). Tier 1 approach is fuel-based, since emissions from all sources of combustion can be estimated on the basis of the quantities of fuel combusted (usually from national energy statistics) and default emission factors (as presented later in this section). The quality of these emission factors differs between gases. The emission factors for $\mathrm{CO}_{2}, \mathrm{CH}_{4}$ and $\mathrm{N}_{2} \mathrm{O}$ mainly depend upon the carbon content of the fuel. Combustion conditions (combustion efficiency, carbon retained in slag and ashes etc.) are relatively unimportant. Therefore, GHGs emissions can be estimated accurately to an extent based on the total amount of fuels combusted and the averaged carbon content of the fuels (IPCC, 2006). The Tier 1 approach calculates
$\mathrm{CO}_{2}, \mathrm{CH}_{4}$ and $\mathrm{N}_{2} \mathrm{O}$ emissions by multiplying estimated fuel sold with a default $\mathrm{CO}_{2}, \mathrm{CH}_{4}$ and $\mathrm{N}_{2} \mathrm{O}$ emission factor. The approach is represented using the following expressions (IPCC, 2006):

$$
\begin{aligned}
& \text { 1. } \mathrm{E}_{\mathrm{i}, \mathrm{G}} \text { (tons) }=\left(\mathrm{V}_{\mathrm{G}}(\mathrm{l}) \times \rho_{\mathrm{G}}\left(\frac{\mathrm{kg}}{\mathrm{l}}\right) \times \mathrm{HHV}_{\mathrm{G}}\left(\frac{\mathrm{MJ}}{\mathrm{kg}}\right) \times \mathrm{EF}_{\mathrm{i}, \mathrm{G}}\left(\frac{\mathrm{kg}}{\mathrm{T} \mathrm{J}}\right) \times\right. \\
& 10^{-9} \text { (tons)) } \\
& \text { 2. } \mathrm{E}_{\mathrm{i}, \mathrm{D}} \text { (tons) }=\left(\begin{array}{c}
\mathrm{V}_{\mathrm{D}}(\mathrm{l}) \times \rho_{\mathrm{D}}\left(\frac{\mathrm{kg}}{\mathrm{l}}\right) \times \mathrm{HHV}_{\mathrm{D}}\left(\frac{\mathrm{MJ}}{\mathrm{kg}}\right) \times \mathrm{EF}_{\mathrm{i}, \mathrm{D}}\left(\frac{\mathrm{kg}}{\mathrm{TJ}}\right) \\
\times 10^{-9}(\text { tons })
\end{array}\right) \\
& 3 \text { Total GHGs }\left(\mathrm{tCO}_{2} \mathrm{e}\right)=\left(\left(1 \times \mathrm{CO}_{2} \text { emissions }\right)+(21 \times\right. \\
& \left.\left.\mathrm{CH}_{4} \text { emissions }\right)+\left(310 \times \mathrm{N}_{2} \mathrm{O} \text { emissions }\right)\right) \text {. }
\end{aligned}
$$

$\mathrm{i}=$ Specific GHG $\left(\mathrm{CO}_{2}, \mathrm{CH}_{4}\right.$ and $\left.\mathrm{N}_{2} \mathrm{O}\right)$ released from combustion of gasoline or diesel;

$\mathrm{E}_{\mathrm{i}, \mathrm{G}}=$ Emission of a specific GHG from combustion of gasoline in tons;

$\mathrm{E}_{\mathrm{i}, \mathrm{D}}=$ Emission of a specific GHG from combustion of diesel in tons;

$\rho_{\mathrm{G}}=$ Density of gasoline $(0.745 \mathrm{~kg} / \mathrm{l})$;

$\rho_{\mathrm{D}}=$ Density of diesel $(0.832 \mathrm{~kg} / \mathrm{l})$;

$\mathrm{V}_{\mathrm{G}}=$ Volume of gasoline in liters;

$\mathrm{V}_{\mathrm{D}}=$ Volume of diesel in liters;

$\mathrm{HHV}_{\mathrm{D}}=$ Higher heating value of diesel (45.77 MJ/kg);

$\mathrm{HHV}_{\mathrm{G}}=$ Higher heating value of gasoline $(46.54 \mathrm{MJ} / \mathrm{kg})$;

$\mathrm{EF}_{\mathrm{G}}=$ Emission factor of $\mathrm{CO}_{2}$ for gasoline engine (69300 $\mathrm{kg} / \mathrm{TJ})$;

$\mathrm{EF}_{\mathrm{D}}=$ Emission factor of $\mathrm{CO}_{2}$ for diesel engine (74100 $\mathrm{kg} / \mathrm{TJ})$;

$\mathrm{EF}_{\mathrm{G}}=$ Emission factor of $\mathrm{CH}_{4}$ for gasoline engine $(18 \mathrm{~kg} / \mathrm{TJ})$; $\mathrm{EF}_{\mathrm{D}}=$ Emission factor of $\mathrm{CH}_{4}$ for diesel engine $(3.85 \mathrm{~kg} / \mathrm{TJ})$;

$\mathrm{EF}_{\mathrm{G}}=$ Emission factor of $\mathrm{N}_{2} \mathrm{O}$ for gasoline engine (1.9 $\mathrm{kg} / \mathrm{TJ})$

$\mathrm{EF}_{\mathrm{D}}=$ Emission factor of $\mathrm{N}_{2} \mathrm{O}$ for diesel engine $(2.25 \mathrm{~kg} / \mathrm{TJ})$; The emission factors and the Equations used in this study were obtained from the literature as provided by IPCC (2006).

As an example, the emission values for $\mathrm{CO}_{2}, \mathrm{CH}_{4}, \mathrm{~N}_{2} \mathrm{O}$ and total GHGs was evaluated for the year 1980 using data (from NNPC) on volumes of gasoline and diesel consumed.

For year 1980,

$$
\begin{aligned}
& \text { 1. } \mathrm{E}_{\mathrm{i}, \mathrm{G}}=\mathrm{E}_{\mathrm{CO}_{2}, \mathrm{G}}+\mathrm{E}_{\mathrm{CH}_{4}, \mathrm{G}}+\mathrm{E}_{\mathrm{N}_{2} \mathrm{O}, \mathrm{G}}=\left(\mathrm{V}_{\mathrm{G}} \times \rho_{\mathrm{G}} \times \mathrm{HHV}_{\mathrm{G}} \times\right. \\
& \left.\mathrm{EF}_{\mathrm{CO}_{2, \mathrm{G}}} \times 10^{-9}\right)_{\mathrm{CO}_{2, \mathrm{G}}}+\left(\mathrm{V}_{\mathrm{g}} \times \rho_{\mathrm{G}} \times \mathrm{HHV}_{\mathrm{G}} \times \mathrm{EF}_{\mathrm{CH}_{4, \mathrm{G}}} \times\right. \\
& \left.10^{-9}\right)_{\mathrm{CH}_{4, \mathrm{G}}}+\left(\mathrm{V}_{\mathrm{G}} \times \rho_{\mathrm{G}} \times \mathrm{HHV}_{\mathrm{G}} \times \mathrm{EF}_{\mathrm{N}_{2 \mathrm{O}, \mathrm{G}}} \times 10^{-9}\right)_{\mathrm{N}_{2 \mathrm{O}, \mathrm{G}}} \\
& \mathrm{E}_{\mathrm{i}, \mathrm{G}}=\left(\mathrm{V}_{\mathrm{G}} \times \rho_{\mathrm{G}} \times \mathrm{HHV}_{\mathrm{G}} \times 10^{-9}\right)\left[\left(\mathrm{EF}_{\mathrm{CO}_{2, \mathrm{G}}}\right)_{\mathrm{CO}_{2, \mathrm{G}}}\right. \\
& \left.+\left(\mathrm{EF}_{\mathrm{CH}_{4, \mathrm{G}}}\right)_{\mathrm{CH}_{4, \mathrm{G}}}+\left(\mathrm{EF}_{\mathrm{N}_{2 \mathrm{O}, \mathrm{G}}}\right)_{\mathrm{N}_{2 \mathrm{O}, \mathrm{G}}}\right] \\
& \mathrm{E}_{\mathrm{i}, \mathrm{G}}=(3869818000 \times 0.745 \times 46.54)[(69300)+ \\
& (18)+(1.9)] \\
& \mathrm{E}_{\mathrm{i}, \mathrm{G}}=(9298361.5)_{\mathrm{CO}_{2, \mathrm{G}}}+(2415.16)_{\mathrm{CH}_{4, \mathrm{G}}} \\
& +(254.93)_{\mathrm{N}_{2 \mathrm{O}, \mathrm{G}}} \\
& \text { 2. } \mathrm{E}_{\mathrm{i}, \mathrm{D}}=\mathrm{E}_{\mathrm{CO}_{2}, \mathrm{D}}+\mathrm{E}_{\mathrm{CH}_{4}, \mathrm{D}}+\mathrm{E}_{\mathrm{N}_{2} \mathrm{O}, \mathrm{D}}=\left(\mathrm{V}_{\mathrm{D}} \times \rho_{\mathrm{D}} \times\right. \\
& \left.\mathrm{HHV}_{\mathrm{D}} \times \mathrm{EF}_{\mathrm{CO}_{2, \mathrm{D}}} \times 10^{-9}\right)_{\mathrm{CO}_{2, \mathrm{D}}}+\left(\mathrm{V}_{\mathrm{D}} \times \rho_{\mathrm{D}} \times \mathrm{HHV}_{\mathrm{D}} \times\right.
\end{aligned}
$$




$$
\begin{gathered}
\left.\mathrm{EF}_{\mathrm{CH}_{4, \mathrm{D}}} \times 10^{-9}\right)_{\mathrm{CH}_{4, \mathrm{D}}}+\left(\mathrm{V}_{\mathrm{D}} \times \rho_{\mathrm{D}} \times \mathrm{HHV}_{\mathrm{D}} \times \mathrm{EF}_{\mathrm{N}_{2 \mathrm{O}, \mathrm{D}}} \times\right. \\
\left.10^{-9}\right)_{\mathrm{N}_{2 \mathrm{O}, \mathrm{G}}} \\
\mathrm{E}_{\mathrm{i}, \mathrm{D}}=\left(\mathrm{V}_{\mathrm{D}} \times \rho_{\mathrm{D}} \times \mathrm{HHV}_{\mathrm{D}} \times 10^{-9}\right)\left[\left(\mathrm{EF}_{\mathrm{CO}_{2, \mathrm{D}}}\right)_{\mathrm{CO}_{2, \mathrm{D}}}\right. \\
\left.+\left(\mathrm{EF}_{\mathrm{CH}_{4, \mathrm{D}}}\right)_{\mathrm{CH}_{4, \mathrm{D}}}+\left(\mathrm{EF}_{\mathrm{N}_{2 \mathrm{O}, \mathrm{G}}}\right)_{\mathrm{N}_{2 \mathrm{O}, \mathrm{D}}}\right] \\
\mathrm{E}_{\mathrm{i}, \mathrm{D}}=(2318351 \times 0.83 \times 45.77)[(74100)+(3.85)+ \\
(2.25)] \quad(6541865.9)_{\mathrm{CO}_{2, \mathrm{D}}}+(339.9)_{\mathrm{CH}_{4, \mathrm{D}}} \\
\quad+(198.64)_{\mathrm{N}_{2 O} \mathrm{D}}
\end{gathered}
$$

3. Total GHGs $\left(\mathrm{tCO}_{2} \mathrm{e}\right)=\left(\left(1 \times \mathrm{CO}_{2}\right)+\left(21 \times \mathrm{CH}_{4}\right)+\right.$ $\left.\left(310 \times \mathrm{N}_{2} \mathrm{O}\right)\right)_{\mathrm{G}}+\left(\left(1 \times \mathrm{CO}_{2}\right)+\left(21 \times \mathrm{CH}_{4}\right)+\right.$ $\left.\left(310 \times \mathrm{N}_{2} \mathrm{O}\right)\right)_{\mathrm{D}}$

Total GHGs $\left(\mathrm{tCO}_{2}\right.$ e)

$$
\begin{aligned}
& =((1 \times 9298361.5)+(21 \times 2415.2) \\
& +(310 \times 254.9))_{\mathrm{G}} \\
& +((1 \times 6541865.9)+(21 \times 339.9) \\
& +(310 \times 198.4))_{\mathrm{D}}
\end{aligned}
$$

Total GHGs $\left(\mathrm{tCO}_{2} \mathrm{e}\right)$

$$
\begin{aligned}
& =((9298361.5)+(50718.4) \\
& +(79029.3))_{\mathrm{G}} \\
& +((6541865.9)+(7137.9) \\
& +(61578.4))_{\mathrm{D}}
\end{aligned}
$$

Total GHGs $\left(\mathrm{tCO}_{2} \mathrm{e}\right)$

$$
\begin{aligned}
& =((9428108.46)+(50727.6) \\
& +(79029.36))_{G} \\
& +((6541865.9)+(7137.9) \\
& +(61578.4))_{D}
\end{aligned}
$$

Total GHGs $\left(\mathrm{tCO}_{2} \mathrm{e}\right)=(9428108.2)_{\mathrm{G}}+(6610582.2)_{\mathrm{D}}$

Using dimensional analysis;

$$
\begin{aligned}
& \mathrm{E}_{\mathrm{i}, \mathrm{G}, \mathrm{D}}(\mathrm{kg})=\left(\frac{\mathrm{M}}{\mathrm{L}^{3}} \times \mathrm{L}^{3} \times\left(\mathrm{ML}^{2} \mathrm{~T}^{-3} \times 10^{6}\right) \times\left(\frac{\mathrm{M}}{\mathrm{ML}^{2} \mathrm{~T}^{-3}} \times\right.\right. \\
& \left.\left.10^{-12}\right)\right)=\mathrm{M} \times 10^{6}
\end{aligned}
$$

Where: $\mathrm{M}=$ mass $($ kilogram); $\mathrm{L}=$ length (meter) and $\mathrm{T}=$ time (seconds).

However, Blacksmith Institute (2007) and IPCC (2007) present and assert that the contributions of the GHGs depend on their global warming potentials (GWPs) which measures the absorption of infrared radiation emitted back into the atmosphere, and these actually form major GHGs that contribute to the thermal imbalance of the earth.

\section{B. Data source and processing}

The data used in this present study was sourced from the bulletins released on the official website of the national agency (Nigeria National Petroleum Corporation (NNPC)) in charge of petroleum related matters in the country. Data available and garnered were from 1980 to 2014, spanning a period of 35 years. Necessary conversion of units and all estimations were carried out using Microsoft Excel (2013). It is assumed that the data obtained from NNPC and subsequently used in this study were correct.

\section{Quantitative Uncertainty Analysis Procedure and Methods}

\section{i. Uncertainty Analysis Procedure}

Volumes of fuels (gasoline and diesel) consumed in the country were used as the input parameters for modelling the outputs $\left(\mathrm{CO}_{2}, \mathrm{CH}_{4}, \mathrm{~N}_{2} \mathrm{O}\right.$ and total $\left.\mathrm{GHGs}\right)$ in order to estimate the uncertainty associated with the emission inventory. Empirical formulae as given in Equations (1 - 3) were used in establishing the model. For this study, EasyFit ${ }^{\circledR} 5.6$ (evaluation version) was utilized to fit the input data $\left(\mathrm{V}_{\mathrm{G}}\right.$ (volume of gasoline) and $V_{D}$ (volume of diesel)) into the appropriate probability distribution function while Analytica ${ }^{\circledR}$ (4.5) software was used for modelling the uncertainty of the emission estimate. Thereafter, the probability distribution models of the input parameters $\left(\mathrm{V}_{\mathrm{G}}\right.$ and $V_{D}$ ) were developed as model inputs. The procedure involved the input models, propagations of uncertainty from input parameters to model outputs using Latin hypercube sampling (LHS), which is a Tier 2 method recommended for national GHG inventories (IPCC, 2006). Finally, the quantitative uncertainty associated with GHGs released from the consumption of gasoline and diesel was determined.

\section{ii. Methods for Simulating Uncertainty Propagation}

Currently, both Monte Carlo Simulation (MCS) and LHS are the most generally used numerical simulation methods. The benefit of using MCS is that it can afford an excellent approximation of the output distribution with a sufficient sample size. However, the disadvantage is that it may be necessary to use large sample sizes to obtain a smooth approximation of the probability distribution function. In this present study, LHS - a numerical simulation method - was used for simulating the propagation of probability distributions of all inputs using a model based on simulated random sampling. Minimal Standard which is the default method in Analytica ${ }^{\circledR}$ was used as random number generator while median Latin hypercube is preferred to random Latin hypercube as the default sampling method due to its high accuracy. Using LHS, the values of each uncertain input are not randomly generated. Instead, the probability distribution is first divided into ranges of equal probability, and then one sample is taken from each range (Lu et al., 2013). For some applications with a given simulation sample size, LHS is a more precise numerical simulation method than MCS ( $\mathrm{Lu}$ et al., 2013). 
Table 1: Gasoline consumption and the gases emitted.

\begin{tabular}{|c|c|c|c|c|c|}
\hline \multirow[b]{2}{*}{ Year } & \multirow[b]{2}{*}{$\begin{array}{l}\text { Gasoline } \\
(000 \text { litres })^{\mathrm{a}}\end{array}$} & \multicolumn{4}{|c|}{ Emission (tons) } \\
\hline & & $\mathrm{CO}_{2}$ & $\mathrm{CH}_{4}$ & $\mathbf{N}_{2} \mathrm{O}$ & $\begin{array}{c}\text { Total GHGs } \\
\left(\mathrm{CO}_{2} \mathrm{e}\right)\end{array}$ \\
\hline 1980 & 3869818 & 9298360 & 2415 & 255 & 9428108 \\
\hline 1981 & 4860224 & 11678099 & 3033 & 320 & 11841053 \\
\hline 1982 & 5465344 & 13132077 & 3411 & 360 & 13315320 \\
\hline 1983 & 5651216 & 13578688 & 3527 & 372 & 13768163 \\
\hline 1984 & 5381646 & 12930967 & 3359 & 355 & 13111404 \\
\hline 1985 & 5374591 & 12914016 & 3354 & 354 & 13094216 \\
\hline 1986 & 4894484 & 11760420 & 3355 & 322 & 11924523 \\
\hline 1987 & 4942233 & 11875149 & 3084 & 326 & 12040853 \\
\hline 1988 & 5257146 & 12631819 & 3281 & 346 & 12808082 \\
\hline 1989 & 5961088 & 14202606 & 3689 & 389 & 14400787 \\
\hline 1990 & 5901055 & 14178997 & 3683 & 389 & 14376848 \\
\hline 1991 & 5904312 & 14186823 & 3685 & 389 & 14384784 \\
\hline 1992 & 5946668 & 14288596 & 3711 & 392 & 14487976 \\
\hline 1993 & 7212077 & 17329109 & 4501 & 475 & 17570917 \\
\hline 1994 & 7622474 & 18315206 & 4757 & 502 & 18570773 \\
\hline 1995 & 5580844 & 13409597 & 3483 & 368 & 13596712 \\
\hline 1996 & 5385917 & 12941229 & 3361 & 355 & 13121809 \\
\hline 1997 & 5911286 & 14203581 & 3689 & 389 & 14401775 \\
\hline 1998 & 3699548 & 8889238 & 2309 & 244 & 9013277 \\
\hline 1999 & 5930124 & 14248845 & 3701 & 391 & 14447671 \\
\hline 2000 & 4761073 & 11439860 & 2971 & 314 & 11599490 \\
\hline 2001 & 7142715 & 17162447 & 4458 & 471 & 17401929 \\
\hline 2002 & 8687595 & 20874470 & 5422 & 572 & 21165748 \\
\hline 2003 & 8725938 & 20966600 & 5446 & 575 & 21259164 \\
\hline 2004 & 8676810 & 20848556 & 5415 & 572 & 21139473 \\
\hline 2005 & 8644260 & 20770345 & 5395 & 569 & 21060171 \\
\hline 2006 & 8306985 & 19959944 & 5184 & 547 & 20238461 \\
\hline 2007 & 8859802 & 21288247 & 5529 & 584 & 21585299 \\
\hline 2008 & 7206729 & 17316258 & 4498 & 475 & 17557886 \\
\hline 2009 & 6876577 & 16522973 & 4292 & 453 & 16753531 \\
\hline 2010 & 6353518 & 15266172 & 3965 & 419 & 15479193 \\
\hline 2011 & 5688450 & 13668152 & 3550 & 375 & 13858875 \\
\hline 2012 & 5017535 & 12056085 & 3131 & 331 & 12224314 \\
\hline 2013 & 3816267 & 9169690 & 2382 & 251 & 9297642 \\
\hline 2014 & 3969710 & 9538380 & 2478 & 262 & 9671477 \\
\hline Total & 213435847 & 736988399 & 133206 & 14061 & 519997702 \\
\hline
\end{tabular}

${ }^{\text {a}}$ Source: NNPC $(1997 ; 1998 ; 2008-2014)$

D. Sensitivity Analysis

The most significant source contributing to the uncertainty associated with the emission inventory from the model inputs were identified using sensitivity analysis. The result of the analysis can assist decision-makers to verify the main sources that make most contributions to the uncertainty in the model output, and to decide where additional data collection are needed for reducing uncertainty in the model inputs. In this study, sensitivity analysis was carried out on the input models to determine the parameter which considerably influences the emission of GHGs.

Table 2: Diesel consumption and the gases emitted.

\begin{tabular}{|c|c|c|c|c|c|}
\hline \multirow[b]{2}{*}{ Year } & \multirow[b]{2}{*}{$\begin{array}{l}\text { Diesel } \\
(000 \text { litres })^{\mathrm{a}}\end{array}$} & \multicolumn{4}{|c|}{ Emission (tons) } \\
\hline & & $\mathrm{CO}_{2}$ & $\mathrm{CH}_{4}$ & $\mathbf{N}_{2} \mathrm{O}$ & $\begin{array}{l}\text { Total } \\
\text { GHGs } \\
\left(\mathrm{CO}_{2} \mathrm{e}\right)\end{array}$ \\
\hline 1980 & 2318351 & 6541866 & 340 & 199 & 6610582 \\
\hline 1981 & 2725912 & 7691911 & 400 & 234 & 7772707 \\
\hline 1982 & 2909688 & 8210486 & 427 & 249 & 8296730 \\
\hline 1983 & 3003085 & 8474031 & 440 & 257 & 8563042 \\
\hline 1984 & 2799597 & 7899833 & 410 & 240 & 7982813 \\
\hline 1985 & 2569897 & 7251673 & 377 & 220 & 7327844 \\
\hline 1986 & 2207401 & 6228790 & 324 & 189 & 6294217 \\
\hline 1987 & 2052459 & 5791580 & 301 & 176 & 5852415 \\
\hline 1988 & 2266466 & 6395457 & 332 & 194 & 6462635 \\
\hline 1989 & 2385501 & 6731348 & 350 & 204 & 8102232 \\
\hline 1990 & 2841477 & 8018010 & 417 & 243 & 6802054 \\
\hline 1991 & 2842682 & 8021409 & 417 & 244 & 8105666 \\
\hline 1992 & 2227829 & 6286432 & 327 & 191 & 6352465 \\
\hline 1993 & 4016018 & 11332301 & 589 & 344 & 11451336 \\
\hline 1994 & 2755092 & 7774252 & 404 & 236 & 7855913 \\
\hline 1995 & 2702682 & 7626362 & 396 & 232 & 7706469 \\
\hline 1996 & 2701144 & 7622021 & 396 & 231 & 7702083 \\
\hline 1997 & 2486369 & 7015975 & 365 & 213 & 7089671 \\
\hline 1998 & 1337987 & 3775499 & 196 & 115 & 3815157 \\
\hline 1999 & 1977203 & 5579223 & 290 & 169 & 5837827 \\
\hline 2000 & 1985639 & 5603027 & 291 & 170 & 5661882 \\
\hline 2001 & 2664542 & 7518739 & 391 & 228 & 7597716 \\
\hline 2002 & 2645976 & 7466350 & 388 & 227 & 7544777 \\
\hline 2003 & 2375711 & 6703723 & 348 & 204 & 6774139 \\
\hline 2004 & 1916000 & 5406522 & 281 & 164 & 5463312 \\
\hline 2005 & 2368000 & 6681964 & 347 & 203 & 6752152 \\
\hline 2006 & 1649749 & 4655221 & 242 & 141 & 4704120 \\
\hline 2007 & 1384956 & 3908036 & 203 & 119 & 3949086 \\
\hline 2008 & 1273203 & 3592693 & 187 & 109 & 3630431 \\
\hline 2009 & 648417 & 1829687 & 95 & 56 & 1848906 \\
\hline 2010 & 879368 & 2481378 & 129 & 75 & 2507442 \\
\hline 2011 & 977892 & 2759391 & 143 & 84 & 2788376 \\
\hline 2012 & 676728 & 1909574 & 99 & 58 & 1929632 \\
\hline 2013 & 733822 & 2070681 & 108 & 63 & 2092432 \\
\hline 2014 & 397898 & 1122779 & 58 & 34 & 1117750 \\
\hline Total & 73704739 & 207978221 & 10806 & 6315 & 730160537 \\
\hline
\end{tabular}




\section{RESULTS AND DISCUSSION}

\section{A. Consumption of gasoline and diesel}

Tables 1 and 2 present the quantities of fuels (gasoline and diesel) and emissions $\left(\mathrm{CO}_{2}, \mathrm{CH}_{4}, \mathrm{~N}_{2} \mathrm{O}\right.$ and total GHGs) for years from 1980 to 2014. The total volume of gasoline and diesel consumed in the country for the period under consideration was $2.13 \times 10^{11}$ litres and $7.37 \times 10^{10}$ litres, respectively. This implies that on volumetric basis, $65.4 \%$ of the fuel consumed was gasoline. Figure 1 gives an illustration of the consumption pattern of gasoline and diesel. It clearly shows that gasoline was consumed more than diesel, as this is evident in both the total volume of the products consumed and the number of ICEs using the products. Though national statistics to this effect is not available but this assertion is based on our personal observation.

A combination of Table 1 and Figure 1 gives a clear view of the consumption of gasoline in the country. As can be seen in Figure 1, the volume of gasoline consumed increased gradually from $3.87 \times 10^{9}$ litres in 1980 to $7.62 \times 10^{9}$ litres in 1994 and then witnessed a rapid reduction in quantity from 1994 to 1998 ( $3.70 \times 10^{9}$ litres). From 1998, the volume of gasoline consumed in the country increased sharply to $8.73 \mathrm{x}$
$10^{9}$ litres in 2003 , which was relatively steady thereafter with a peak in 2007 ( $8.86 \times 10^{9}$ litres). A significant reduction in quantity from $8.86 \times 10^{9}$ litres in 2007 to $3.82 \times 10^{9}$ litres in 2013 was recorded (Figure 1). This was followed by a slight increase in quantity (3.97 x $10^{9}$ litres) in 2014. As observed in Figure 1, the trend of gasoline consumed has its minimum and maximum values in the year 1998 and 2007 which corresponds to $3.70 \times 10^{9}$ litres and $8.86 \times 10^{9}$ litres, respectively.

As could be observed in Figure 1, diesel consumption showed a gradual reduction pattern from $2.32 \times 10^{9}$ litres in 1980 to $3.92 \times 10^{8}$ litres in 2014 . The highest quantity of diesel consumed was recorded in the year 1993 with a value of $4.02 \times 10^{9}$ litres while the lowest volume was in the year $2014\left(3.92 \times 10^{8}\right.$ litres). A correlation coefficient of 0.167 was obtained between the data for gasoline and diesel consumed in the country. This shows a positive and weak relationship between these sets of data. It is therefore evident that both data are independent of another.

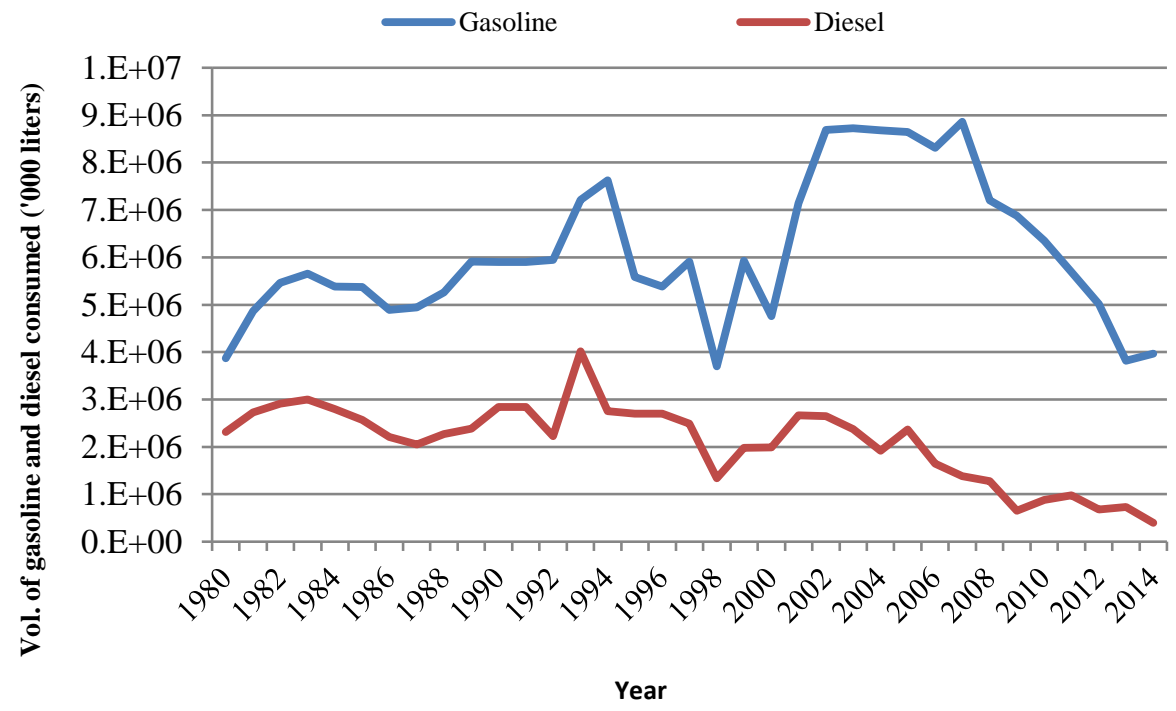

Figure 1: Volume of gasoline and diesel consumed in Nigeria from 1980 to 2014.

\section{B. Greenhouse gases emitted from gasoline consumption}

The emission factors employed in this study for the estimation of $\mathrm{CO}_{2}, \mathrm{CH}_{4}$, and $\mathrm{N}_{2} \mathrm{O}$ were given in Sub-section 2.1 as obtained in literature (IPCC, 2006). The choice of emission factors for both stationary and mobile engines (combustors) was informed by the fuels under consideration in this study. Moreso, due to the unavailability of information in the country concerning the percent or amount of engines and machineries using a type of fuel and under the mobile and stationary category, this led to the use of average emission factor for each GHG under each fuel type and combustor category.
From Table 1, the quantities of $\mathrm{CO}_{2}, \mathrm{CH}_{4}$ and $\mathrm{N}_{2} \mathrm{O}$ released into the atmosphere from gasoline consumption for the period in view are presented. Total amount of GHGs emitted was $5.20 \times 10^{8}$ tons of $\mathrm{CO}_{2}$ equivalent $\left(\mathrm{t} \mathrm{CO}_{2} \mathrm{e}\right)$ which translates to emission of $1.33 \times 10^{5}$ tons of $\mathrm{CH}_{4}, 1.41 \times 10^{4}$ tons of $\mathrm{N}_{2} \mathrm{O}$ and $5.13 \times 10^{8}$ tons of $\mathrm{CO}_{2}$. Based on these values, yearly average of $3.80 \times 10^{3}$ tons, 401.7 tons and 1.47 x $10^{7}$ tons of $\mathrm{CH}_{4}, \mathrm{~N}_{2} \mathrm{O}$ and $\mathrm{CO}_{2}$, respectively, were released into the environment. For the year 2014, $9.67 \times 10^{6} \mathrm{t} \mathrm{CO}_{2} \mathrm{e}$ of GHGs were emitted into the environment which translates to $\$ 145.07$ million (N44.97 billion at N305 to \$US 1) based on $\$ 15 / t \mathrm{CO}_{2} \mathrm{e}(\mathrm{N} 4725)$ carbon tax. As seen in Figure 2, the same pattern was observed for the amounts of $\mathrm{CO}_{2}, \mathrm{CH}_{4}$ and $\mathrm{N}_{2} \mathrm{O}$ 
emitted which is similar to the pattern noticed in Figure 1 for the volume of gasoline consumed. This can be attributed to the linear nature of the mathematical expressions used for the estimation of the quantities of GHGs. It is worth noting that $98.62 \%$ of the total GHGs $\left(\mathrm{CO}_{2}, \mathrm{CH}_{4}\right.$ and $\left.\mathrm{N}_{2} \mathrm{O}\right)$ released into the atmosphere as a result of gasoline burning in combustors was $\mathrm{CO}_{2}$. Significantly small amounts of $\mathrm{N}_{2} \mathrm{O}\left(4.36 \times 10^{6} \mathrm{t}\right.$ $\left.\mathrm{CO}_{2} \mathrm{e}\right)$ and $\mathrm{CH}_{4}\left(2.80 \times 10^{6} \mathrm{t} \mathrm{CO}_{2} \mathrm{e}\right)$ was emitted compared to $\mathrm{CO}_{2}\left(5.13 \times 10^{8}\right.$ tons) for the year span (1980 to 2014) under consideration.

\section{Greenhouse gases emitted from diesel consumption}

The amounts of $\mathrm{CO}_{2}, \mathrm{CH}_{4}$ and $\mathrm{N}_{2} \mathrm{O}$ emitted during the consumption of diesel for 35 years are provided in Table 2. Total amount of GHGs released into the atmosphere for using diesel was $2.10 \times 10^{8} \mathrm{t} \mathrm{CO}_{2} \mathrm{e}$. This quantity comprises of 1.08 x $10^{4}$ tons of $\mathrm{CH}_{4}, 6.32 \times 10^{3}$ tons of $\mathrm{N}_{2} \mathrm{O}$ and $2.08 \times 10^{8}$ tons of $\mathrm{CO}_{2}$. On yearly average, 308.7 tons, 180.4 tons and $5.94 \mathrm{x}$ $10^{6}$ tons of $\mathrm{CH}_{4}, \mathrm{~N}_{2} \mathrm{O}$ and $\mathrm{CO}_{2}$, respectively, were released into the atmosphere. It is apparent that the same trend of emissions (amount of $\mathrm{CO}_{2}, \mathrm{CH}_{4}$ and $\mathrm{N}_{2} \mathrm{O}$ ) noticed in Figure 3 was observed in Figure 1 for the volume of diesel consumed in the country. Again, the quantity of $\mathrm{CO}_{2}$ was significantly higher than other gases as shown in Figure 2 and as given in Table 2. This supports the fact that $\mathrm{CO}_{2}$ is a major global warming contributor despite its low global warming potential of 1, compared to those of $\mathrm{CH}_{4}$ (21) and $\mathrm{N}_{2} \mathrm{O}$ (310) in terms of $\mathrm{CO}_{2} \mathrm{e}$.

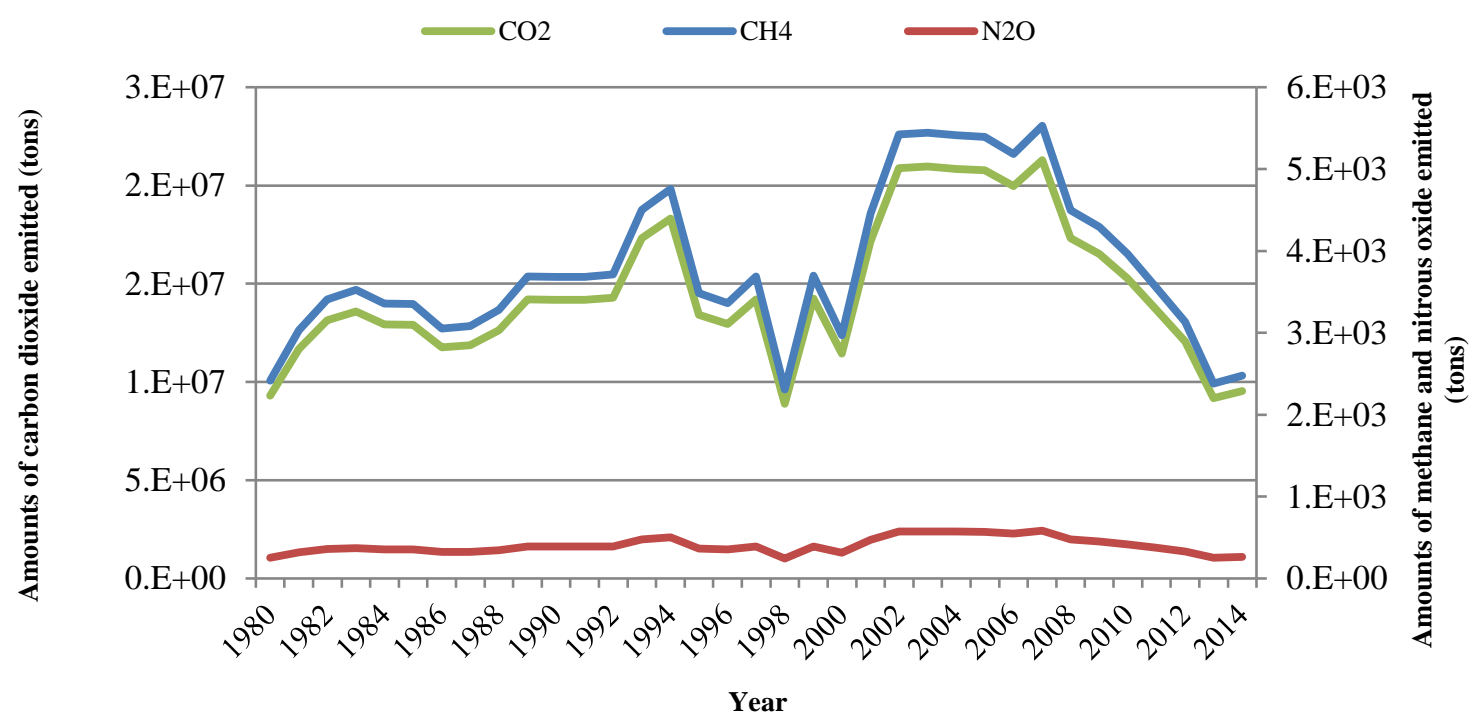

Figure 2: Amounts of $\mathrm{CO}_{2}, \mathrm{CH}_{4}$ and $\mathrm{N}_{2} \mathrm{O}$ released from gasoline consumption in Nigeria.

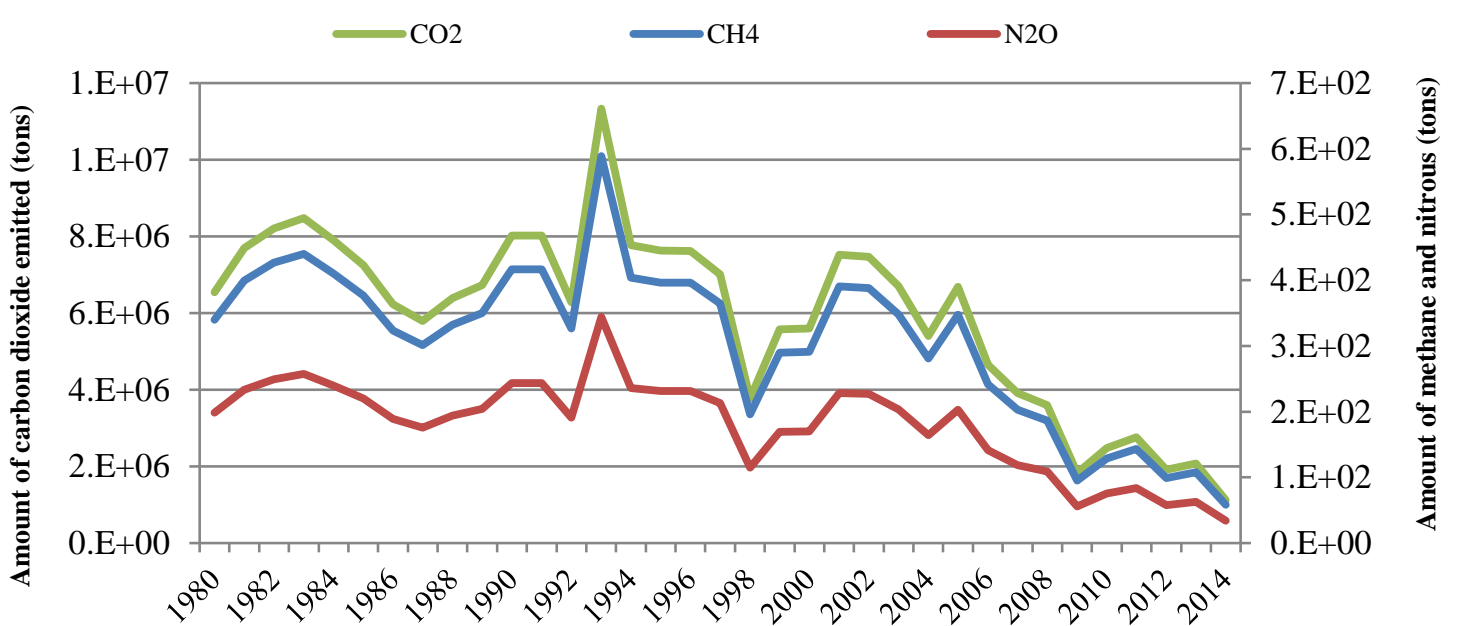

Year

Figure 3: Amounts of $\mathrm{CO}_{2}, \mathrm{CH}_{4}$ and $\mathrm{N}_{2} \mathrm{O}$ released from diesel consumption in Nigeria. 
D. Total GHGs emitted from gasoline and diesel consumption

The estimated amount of GHGs emitted from the consumption of gasoline and diesel was $5.20 \times 10^{8} \mathrm{t} \mathrm{CO}_{2} \mathrm{e}$ and $2.10 \times 10^{8} \mathrm{t} \mathrm{CO}_{2} \mathrm{e}$, respectively (Tables 1 and 2). In terms of carbon tax at the present rate of $\$ 15 / \mathrm{t} \mathrm{CO}_{2} \mathrm{e}(\mathrm{N} 4725)$, these values sum up to $\$ 7.80$ billion ( $\mathrm{N} 2.38$ trillion) and $\$ 3.15$ billion (N960.75), respectively. From Figure 4, it is clear that the quantity of GHGs released as a result of the consumption of gasoline is more than that of diesel. This can be linked with the volume of gasoline consumed during the period in view compared to that of diesel. A total of $7.30 \times 10^{8} \mathrm{t} \mathrm{CO}_{2} \mathrm{e}$ of GHGs was estimated to be released into the environment due to the consumption of $2.15 \times 10^{11}$ litres of gasoline and $7.45 \times 10^{10}$ litres of diesel for the 35 -year period in the country. From Tables 1 and 2, it was estimated that $71.23 \%$ of the total GHGs was as a result of the consumption of gasoline as fuel. Of the estimated total amount of GHGs emitted into the environment, $\mathrm{CO}_{2}$ emission accounted for $98.96 \%$ of the amount. The cost of carbon tax for the total amount of GHGs was $\$ 109.52$ billion (N33.40 trillion) while that for the emissions in the year 2014 was $\$ 161.84$ million (N49.36 billion).

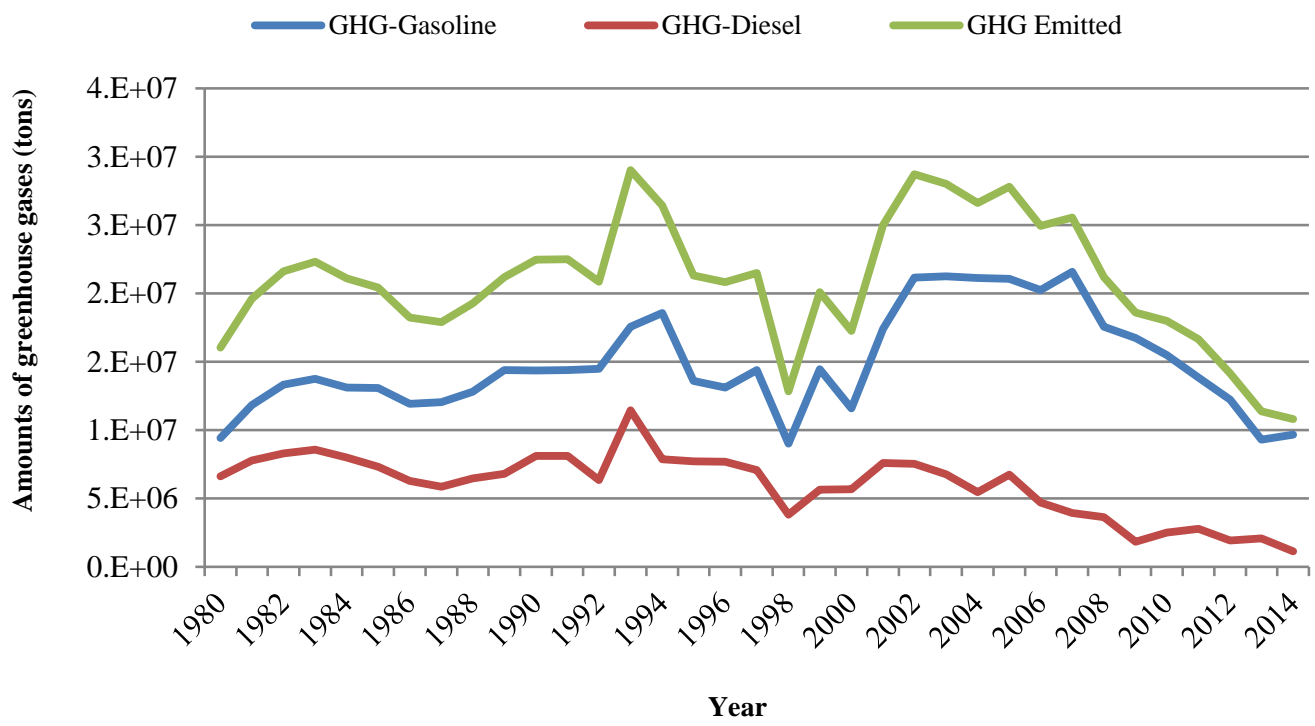

Figure 4: Amounts of greenhouse gases released from petroleum products consumption.

According to a report on national GHG inventory under UNFCC for the year 2000, Nigeria contributed about $2.14 \mathrm{x}$ $10^{8} \mathrm{t} \mathrm{CO}_{2} \mathrm{e}$ of $\mathrm{GHG}$ to the atmosphere (National Communication, 2014). The energy sector (fuel combustion and fugitive emissions) was reported to contribute the largest proportion $(70 \%)$ to direct $\mathrm{GHG}$ emissions in Nigeria (National Communication, 2014). Of this amount, $1.33 \times 10^{8}$ $\mathrm{tCO}_{2} \mathrm{e}$ were released into the atmosphere due to fuel combustion which consisted of $1.15 \times 10^{8}$ tons $(114,724 \mathrm{Gg})$ of $\mathrm{CO}_{2}, 6.79 \times 10^{8}$ tons $(679 \mathrm{Gg})$ of $\mathrm{CH}_{4}$ and $9.0 \times 10^{3}$ tons $(9$ $\mathrm{Gg}$ ) of $\mathrm{N}_{2} \mathrm{O}$. From this present study, it was estimated that $1.70 \times 10^{7}$ tons of $\mathrm{CO}_{2}, 3.26 \times 10^{3}$ tons of $\mathrm{CH}_{4}$ and 484 tons of $\mathrm{N}_{2} \mathrm{O}\left(1.73 \times 10^{7} \mathrm{t} \mathrm{CO}_{2} \mathrm{e}\right)$ were emitted through the use of both gasoline and diesel in the year 2000. From the values aforementioned, it was observed that this study's estimate of GHGs is $13.1 \%$ of that reported for the energy sector in the national GHG inventory. This consists of $14.5 \%\left(\mathrm{CO}_{2}\right), 0.5$ $\%\left(\mathrm{CH}_{4}\right)$ and $5.4 \%\left(\mathrm{~N}_{2} \mathrm{O}\right)$ of the corresponding gas reported in the energy sector. The significant difference between the value of GHGs obtained in this study and that reported for the sector in the national inventory is largely due to the encompassing inventory of the emissions in the energy sector (energy industries, manufacturing and construction, transport, commercial, residential, agriculture, forestry and fishing activities, gas flaring, petroleum refining and fugitive process) of the country as against the GHG estimation of emissions from gasoline and diesel consumption. Also, 40.3 $\%\left(5.66 \times 10^{7} \mathrm{t} \mathrm{CO}_{2} \mathrm{e}\right)$ of the GHGs from the energy sector were reported to be from gas flaring activities for the year under consideration (National communication, 2014). In addition, the transport subsector of the energy sector was reported to have emitted $2.57 \times 10^{7} \mathrm{t} \mathrm{CO}_{2} \mathrm{e}$ of GHGs into the atmosphere, which is an amount fairly higher than the value $\left(1.73 \times 10^{7} \mathrm{t} \mathrm{CO}_{2} \mathrm{e}\right)$ obtained in this study. It is worth mentioning that the GHG inventory for the transport subsector entailed emissions from road, rail, aviation and marine sections. 


\section{E. Comparison of results}

To our best knowledge, previous studies on GHGs emission inventory for gasoline and diesel fuels in Nigeria are very scarce in the literature. Thus, we have compared our results with data provided in this regard by government agencies and institutions such as United States Energy Information (USEIA), World Bank, United States Department of Energy (USDOE), and Emission Database for Global Atmospheric Research (EDGAR). Emissions of $\mathrm{CO}_{2}$, $\mathrm{CH}_{4}$ and $\mathrm{N}_{2} \mathrm{O}$ as obtained in our study were compared with those provided by USEIA, World Bank and USDOE (for $\mathrm{CO}_{2}$ ) and EDGAR (for both $\mathrm{CH}_{4}$ and $\mathrm{N}_{2} \mathrm{O}$ emissions).

Figure 5 illustrates the amounts of $\mathrm{CO}_{2}$ released via fossil fuel combustion in Nigeria from 1980 to 2014 as obtained from USEIA, USDOE and World Bank, and this present study. It is pertinent to know that $\mathrm{CO}_{2}$ emission data for both USEIA and World Bank were only updated to the year 2013 as at the time of reporting this work while those of USDOE were given to the year 2014. From Figure 5, it can be noticed that the values of $\mathrm{CO}_{2}$ emissions evaluated in this study were slightly lower than those of USEIA, USDOE and World Bank. This can be linked to the fact that this work only considered $\mathrm{CO}_{2}$ emission inventory for gasoline and diesel of all the fossil fuels (kerosene, natural gas etc.) used in the country. Thus, the difference in emission values observed in Figure 5 can be due to the other fossil fuels not accounted for in our study but evaluated by USEIA and USDOE. Analysis of variance (ANOVA) carried out on all the $\mathrm{CO}_{2}$ data from USDOE, USEIA, World Bank and this study showed that the values were significant and statistically different $\left(\mathrm{F}_{\text {observed }}\right.$ (78.26) $>\mathrm{F}_{\text {critical }}$ (3.99)) from one another with P-value $<<0.05$ at $95 \%$ confidence level. Beside USDOE and World Bank having correlation coefficient of unity (1) - showing excellent relationship between the $\mathrm{CO}_{2}$ data sources - other $\mathrm{CO}_{2}$ data correlations revealed weak and positive correlation coefficients (USEIA and World Bank (0.3117), our data and USEIA (0.2519), USDOE and USEIA (0.3116), our data and World Bank (0.2118) and, USDOE and our data (0.3116)).

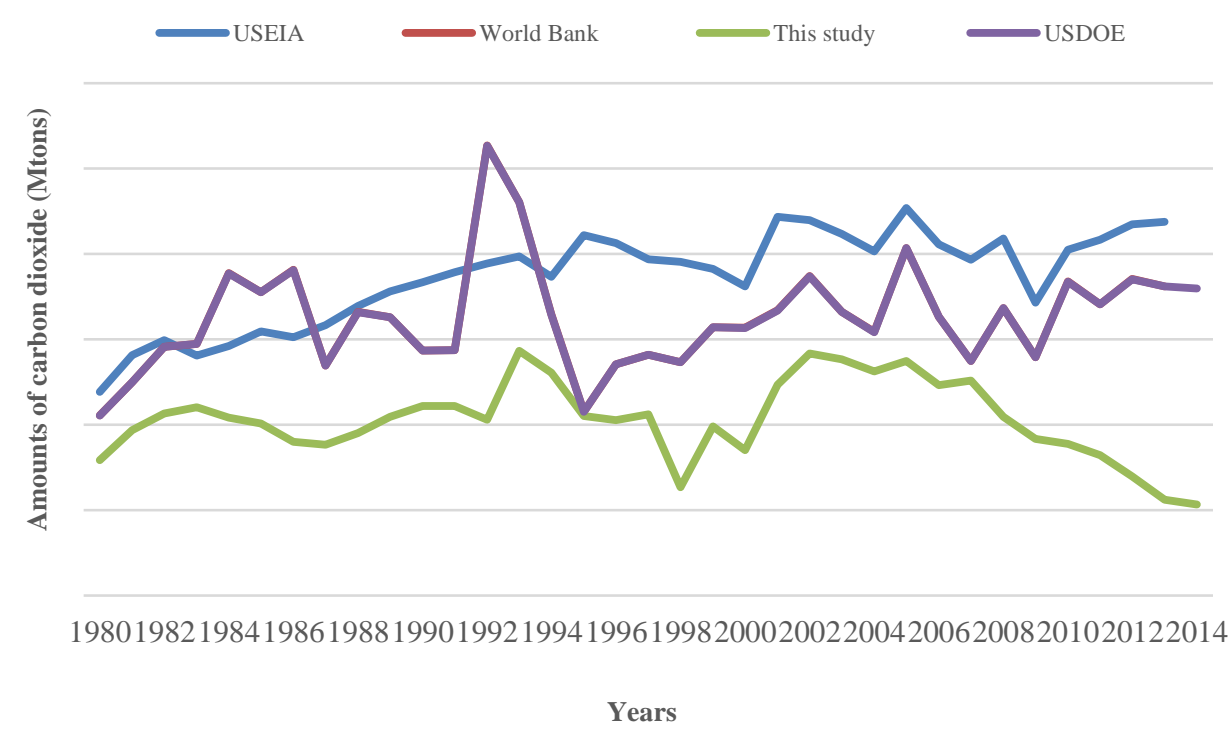

Figure 5: Comparison of present study with other emission data sets $\left(\mathrm{CO}_{2}\right)$.

Comparison between the estimated $\mathrm{CH}_{4}$ emissions in this work and those of EDGAR dataset of $\mathrm{CH}_{4}$ emissions in the country is presented in Figure 6. Relatively similar trends were noticed between the $\mathrm{CH}_{4}$ emission data from 1980 to 1993. Thereafter, a considerably sharp increase in the amounts of $\mathrm{CH}_{4}$ emissions due to fossil fuels burning was observed for the EDGAR $\mathrm{CH}_{4}$ data from 1993 to 2008. This sudden and progressive increase in $\mathrm{CH}_{4}$ emissions from 1993 upward as reflected in EDGAR data for $\mathrm{CH}_{4}$ may be attributed to the monumental use of natural gas in the industrial sector of the country at that point in time as the EDGAR database provides emission values for fossil fuels combustion, of which only gasoline and diesel were considered and evaluated in this present study. The two $\mathrm{CH}_{4}$ emission data were found to be statistically not the same $\left(\mathrm{F}_{\text {observed }}(23.32)>\mathrm{F}_{\text {critical }}(4.01)\right)$, though significant with $\mathrm{P}$ value $<<0.05$ at $95 \%$ confidence level. Also, a moderate and positive relationship was noticed between the two emission data with a correlation coefficient of 0.6281 . 


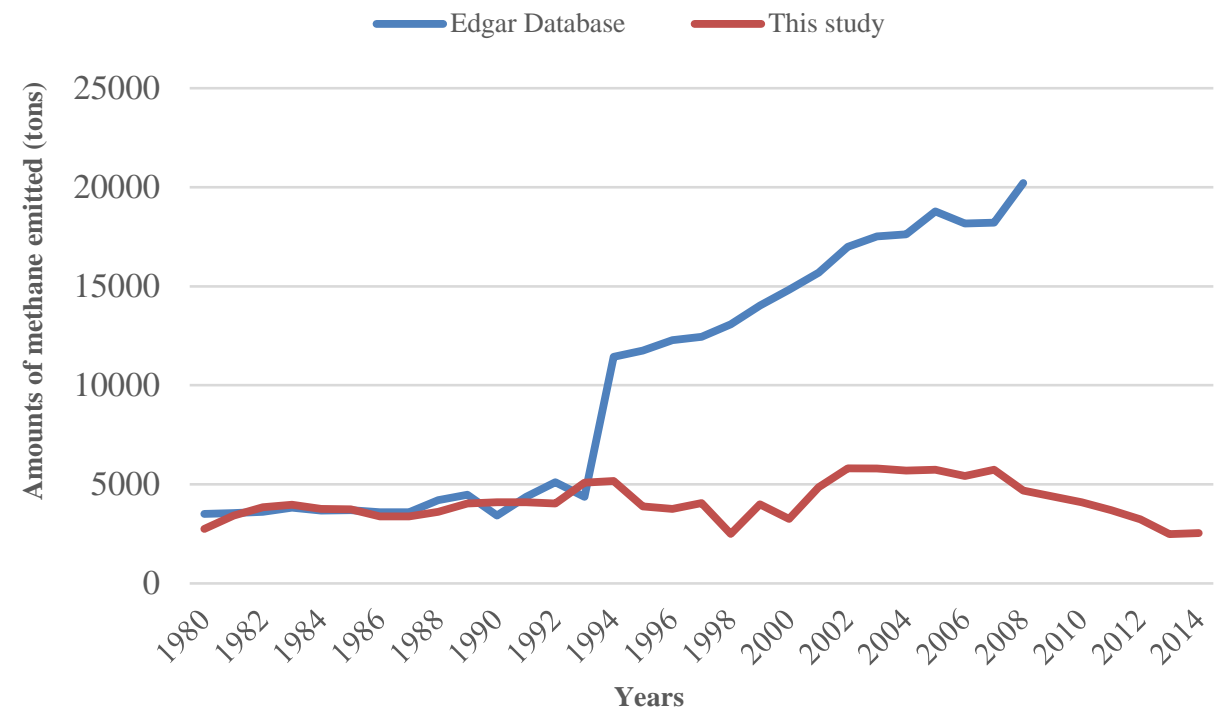

Figure 6: Comparison of present study with other emission data sets $\left(\mathrm{CH}_{4}\right)$.

In comparing the estimated $\mathrm{N}_{2} \mathrm{O}$ emissions obtained in this work with those provided by EDGAR database for $\mathrm{N}_{2} \mathrm{O}$ emissions, similar pattern to that of $\mathrm{CH}_{4}$ emissions comparison (see Figure 6) was noticed in Figure 7. The only exception is the fact that the quantities of $\mathrm{N}_{2} \mathrm{O}$ evaluated in this study were slightly higher than those reported in EDGAR database. Similarly, both data sets were statistically not equal $\left(\mathrm{F}_{\text {observed }}(15.13)>\mathrm{F}_{\text {critical }}(4.0)\right)$ with $\mathrm{P}$-value of 0.00027 at 95 $\%$ confidence level and correlation coefficient of 0.3814 . These implied the significance of both data and the existence of a weak-positive relationship between them.

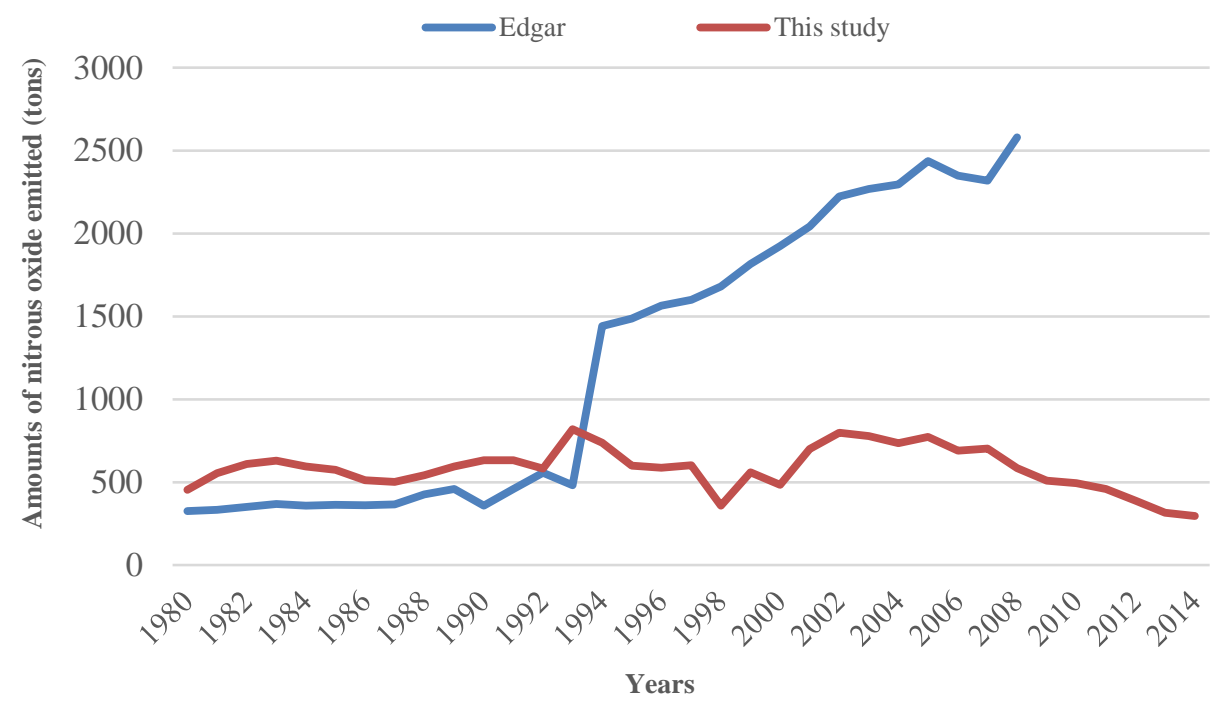

Figure 7: Comparison of present study with other emission data sets $\left(\mathrm{N}_{2} \mathrm{O}\right)$.

F. Quantitative estimates of uncertainty

i. Uncertainty analysis for total emission

The quality of emission inventories for the GHGs depends largely on the accuracy of fuel consumption statistics. In this study, the GHGs emissions inventory have been carried out base on standard and best practices subject to the data available to us through NNPC. However, we strongly encourage better and extensive collection of these data taking into account the volume of gasoline and diesel consumed by the end users. By this, we meant reliable data that has taken care of possible smuggling these products, tanker accidents, proper accounting of fuels at their final destinations across the country etc. The data on volumes of gasoline and diesel obtained from NNPC were considered to be significantly sufficient for use in study bearing in mind possible but insignificant inappropriateness and bias in data collection due to both systematic and human errors. 
Tier 2 approach was chosen for this study because the coefficient of variation for the input variables was more than $0.3(0.57)$ and that the input variables did not fit into normal distribution. Goodness-of-fit tests (Chi-Squared test, Kolmogorov-Smirnov test, and Anderson-Darling test) carried out on the input parameters using EasyFit@ assigned lognormal and triangle distributions to $\mathrm{V}_{\mathrm{G}}$ and $\mathrm{V}_{\mathrm{D}}$, respectively. Based on these distributions, the range of the mean of $\mathrm{CO}_{2}, \mathrm{CH}_{4}, \mathrm{~N}_{2} \mathrm{O}$ and total GHGs at $95 \%$ confidence was obtained by running the simulation on Analytica ${ }^{\circledR}$.

Table 3 gives the simulated mean, relative uncertainties of the mean, lower and upper confidence levels of the mean for the quantity of emissions $\left(\mathrm{CO}_{2}, \mathrm{CH}_{4}, \mathrm{~N}_{2} \mathrm{O}\right.$ and total GHGs) released into the environment from petroleum products consumed. The estimated mean of $\mathrm{CO}_{2}, \mathrm{CH}_{4}, \mathrm{~N}_{2} \mathrm{O}$ and total GHGs obtained prior to quantifying the estimate of uncertainties associated with them was found to be relatively higher than those obtained for the simulated mean as presented in Table 3. These discrepancies in the mean may be ascribed to the nature and statistical distribution of the input data, the collection and mode of collection of the data by the national agency. For this study, the running of the simulation model was carried out using 250, 500, 1000, 2000 and 3000 iterations, respectively. The simulation with 3000 iterations was considered the best for the output model since the standard deviation remained constant at this number of iteration.

Table 3: Uncertainties of GHGs from gasoline and diesel consumption $(1980-2014)$ in Nigeria (number of trails $=3000)$.

\begin{tabular}{ccccccc}
\hline Emission & Min. (2.5th CL) & Mean & Max. (97.5th CL) & \multicolumn{2}{c}{ Relative uncertainty } & Estimated \\
\hline $\mathrm{CO}_{2}$ & $1.138 \mathrm{M}$ & $5.964 \mathrm{M}$ & $10.640 \mathrm{M}$ & $-80.91 \%$ & $78.40 \%$ & $6.002 \mathrm{M}$ \\
$\mathrm{N}_{2} \mathrm{O}$ & $36.49 \mathrm{~K}$ & $191.30 \mathrm{~K}$ & $341.30 \mathrm{~K}$ & $-80.93 \%$ & $78.41 \%$ & $192.5 \mathrm{~K}$ \\
$\mathrm{CH}_{4}$ & $55.95 \mathrm{~K}$ & $293.40 \mathrm{~K}$ & $523.40 \mathrm{~K}$ & $-80.93 \%$ & $78.39 \%$ & 295.2 \\
Total GHGs & $13.62 \mathrm{M}$ & $71.43 \mathrm{M}$ & $127.40 \mathrm{M}$ & $-80.93 \%$ & $78.36 \%$ & $71.88 \mathrm{M}$ \\
\hline
\end{tabular}

Note: $\mathrm{CL}=$ Confidence level: Negative random error $=(2.5$ th percentile-mean $) /$ mean; positive random error $=(97.5$ th percentile-mean $) /$ mean;

$\mathrm{M}=$ million $\left(10^{6}\right) ; \mathrm{K}=$ thousand $\left(\mathbf{1 0}^{3}\right)$.

\section{ii. Estimating Uncertainty in the Model Output}

As observed in Table 3 , the range of the total amount of GHGs emitted is between $1.36 \times 10^{7} \mathrm{tCO}_{2} \mathrm{e}$ and $1.27 \times 10^{8}$ $\mathrm{tCO}_{2} \mathrm{e}$ with the corresponding relative uncertainties of -80.93 $\%$ and $78.36 \%$. This is clearly illustrated in the cumulative probability distribution of the output model as presented in Figure 8. Also, the ranges of the total $\mathrm{CO}_{2}, \mathrm{CH}_{4}$ and $\mathrm{N}_{2} \mathrm{O}$ are presented in Table 3. The simulated mean values are $5.96 \times$ $10^{6}$ tons, $2.93 \times 10^{5}$ tons, $1.91 \times 10^{5}$ tons and $7.14 \times 10^{7} \mathrm{tCO}_{2}$ e for $\mathrm{CO}_{2}, \mathrm{CH}_{4}, \mathrm{~N}_{2} \mathrm{O}$ and total GHGs, respectively. The relative uncertainties associated with $\mathrm{CO}_{2}, \mathrm{CH}_{4}$ and $\mathrm{N}_{2} \mathrm{O}$ are also presented in Table 3.

The range of relative uncertainty obtained for each emission parameter $\left(\mathrm{CO}_{2}, \mathrm{CH}_{4}, \mathrm{~N}_{2} \mathrm{O}\right.$ and total GHGs) is strongly connected to the mode of collection and nature of the data used in evaluating the uncertainties. The values of the ranges of relative uncertainty as presented in column 5 of Table 3, seems similar due to the characteristics of the data as the same data were employed in the estimation of the relative uncertainties. Columns 2, 3 and 4 of Table 3, show the minimum, mean and maximum values, respectively, of the simulated quantities of the emission parameters of $\mathrm{CO}_{2}, \mathrm{CH}_{4}$, $\mathrm{N}_{2} \mathrm{O}$ and total GHGs (at $95 \%$ confidence level), obtained using Analytica ${ }^{\circledR}$ (4.5) to estimate uncertainties associated with the parameters. The columns present statistical values of emissions connected to the cumulative probability distributions generated for all the emission parameters. From Figure 8 , it can be observed that the minimum value of total GHGs is more than $10 \mathrm{M}$ and less than $20 \mathrm{M}$ (around $14 \mathrm{M}$ ) while the maximum value is above $120 \mathrm{M}$ and less than 140 $\mathrm{M}$ (around $130 \mathrm{M}$ ). These values are close to those (minimum and maximum values) reported for total GHGs in Table 3.

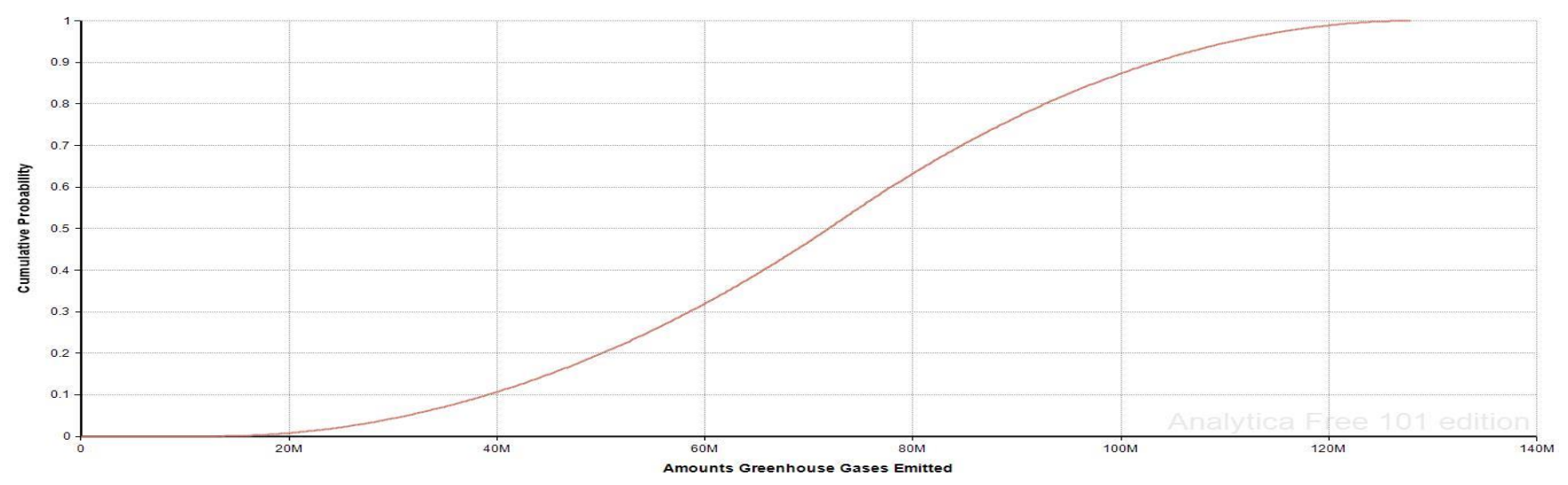

Figure 8: Uncertainty analysis on total GHGs emitted from gasoline and diesel consumption. 


\section{iii. Sensitivity analysis on emission}

It was observed that out of the two input parameters $\left(V_{G}\right.$ and $V_{D}$ ) that contribute to the estimation of the total GHGs, $V_{D}$ is more sensitive to the uncertainty of the emission estimates (see Figure 6). The result of the sensitivity analysis implies that the best way to reduce uncertainty in the total amount of GHGs is to reduce uncertainty in the data of $V_{D}$ with more accurate data collection and the use of state-of-theart instruments.

\section{iv. Solutions to reduce GHGs emission in Nigeria}

At this point in time when nations of the world are mitigating against the release of emissions (gaseous or particulate), particularly GHGs into the atmosphere from the combustion of fossil fuels, Nigeria as a country is not on the same page as others despite clear evidences of the effects of global warming and climate change in the country. National emission inventory from various sources are scarce, emission regulations and standards are nothing to write about compared to global best practices and the response of successive governments in the country towards emissionrelated issues call for serious concern. Free-to-theenvironment release of emissions from the burning of fossil fuels in various combustors without an atom of restriction from any quarters is the order of the day in the country.

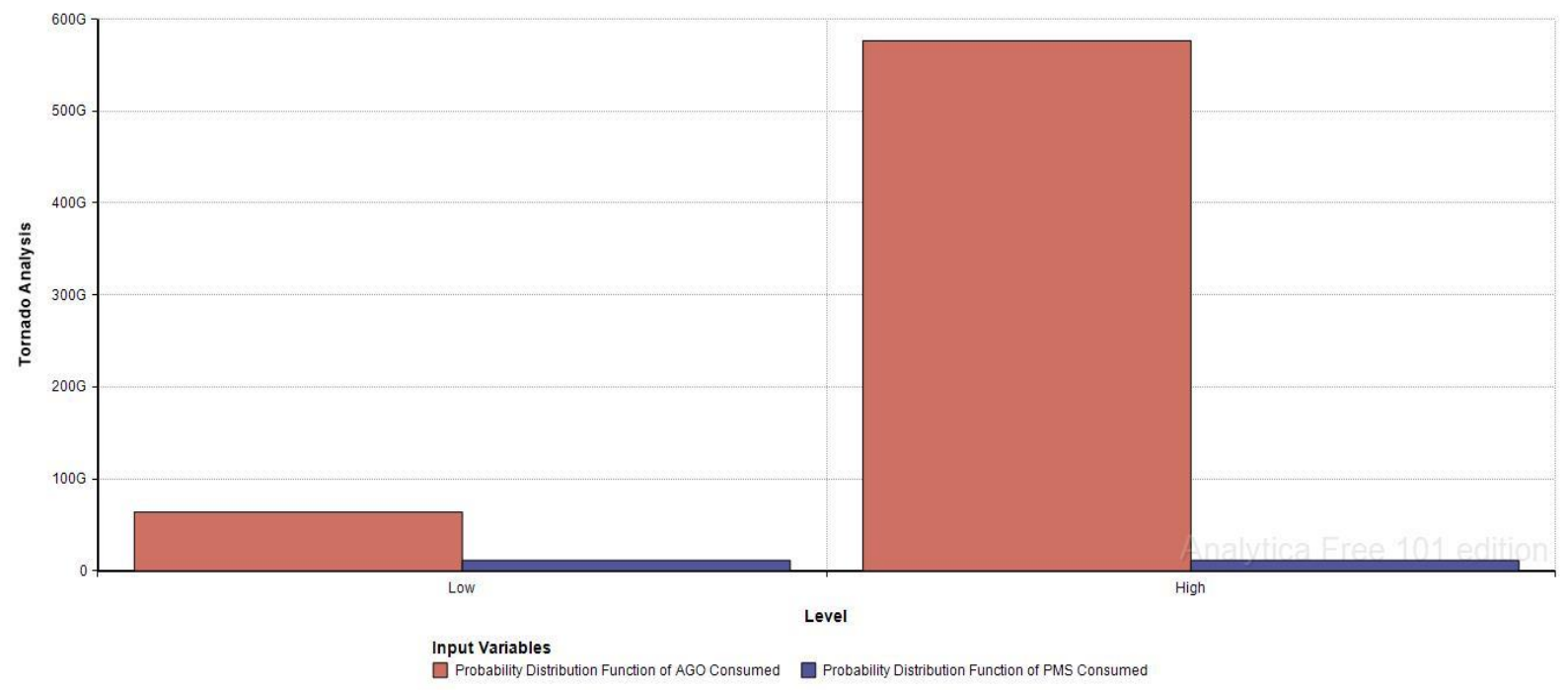

Figure 9: Sensitivity of total GHGs emitted to input parameters.

In agreement with international cry as heralded by various agencies and organizations such as United Nations and IPCC that countries should cut down drastically GHGs emissions, Nigeria being a signatory must see the need to urgently strategize to partake in this global drive toward ensuring a safe world. National policy on emissions should be reformulated which would include undertaking national inventory to quantify emissions from time to time, making rules and regulations on emissions from various sources and enforcing them, setting national emission standards subject to review with time, utilization and enforcement of emissions abatement technologies, use of alternative fuel vehicles, use of low or neutral alternative fuels (biofuels, compressed natural gas and liquefied natural gas) and so on. Solving the erratic power supply problem in the country can also help in reducing emissions since companies, institutions, households, offices, business owners etc. will run on electricity instead of burning fuels in electric generator sets as options available for energy supply.

Subject to the GHG footprint as estimated in this study and in consonance with the international outcry for sustainable development in terms of sustainable energy development and sustainable environment, the large quantity of $\mathrm{CO}_{2}$ from consumption of gasoline and diesel needs prompt attention. Similarly, the country being a party to the new birth world order of sustainable development must strategize, plan and implement towards achieving the sustainable development goals, especially goals 7 (ensuring access to affordable, reliable and sustainable energy) and 13 (urgent action to combat climate change and its impacts) in agreement to this work.

\section{CONCLUSION}

Burning of fossil fuels (gasoline and diesel) has caused poor indoor and outdoor air quality in the country, which has significantly contributed to public health and environment issues. Using the fuel consumption data with the Tier 1 approach recommended for national GHGs estimation and Analytica $^{\mathrm{TM}}$ software, the total amount of GHGs emitted into the environment for the period under consideration was 7.30 x $10^{8} \mathrm{tCO}_{2 \text { e }}$ (gasoline; $5.20 \times 10^{8} \mathrm{tCO}_{2}$ and diesel; $2.10 \times 10^{8}$ $\mathrm{tCO}_{2}$ e) from $2.13 \times 10^{11}$ and $7.45 \times 10^{10}$ litres of gasoline and diesel, respectively. The range of the total amount of GHGs emitted is between $1.36 \times 10^{7} \mathrm{tCO}_{2} \mathrm{e}$ and $1.27 \times 10^{8} \mathrm{tCO}_{2} \mathrm{e}$ with the relative uncertainties of $-80.93 \%$ and $78.36 \%$. Measures to abate GHGs emission should be put in place and enforced by the government. Currently, no measure is in place in the country to curb emissions from fuel combustion. 
We therefore suggest national policy and its strict enforcement in this direction.

\section{ACKNOWLEDGEMENTS}

The contributions of Osinowo Gbenga and other project students towards the success of this study are highly acknowledged.

\section{REFERENCES}

Aderogba, K. A. (2011). Greenhouse Gas Emissions and Sustainability in Lagos Metropolis, Nigeria. International Journal of Learning and Development, 1 (2): 46-61.

Blacksmith Institute (2007). The World's Worst Polluted Places. Available online at: www.blacksmithinstitute.org/the-2007-top-ten-of-worstpolluted-places.html. Accessed on January 15, 2016.

Boden, T. A.; G. Marland and R. J. Andres. (2013). Global, Regional, and National Fossil-Fuel CO2 Emissions. Carbon Dioxide Information Analysis Center (CDIAC), Oak Ridge National Laboratory, US Department of Energy, Oak Ridge, Tenn., USA doi:10.3334/CDIAC/00001_V2013. http://cdiac.ornl.gov/trends/emis/meth_reg.html

EDGAR (Emission Database for Global Atmospheric Research), (2011). European Commission, Joint Research Centre (JRC)/PBL Netherlands Environmental Assessment Agency. v4.2_EM_CH4_300911 (EDGAR) and v4.2_EM_N2O_final_emitting_111111 (EDGAR). http://edgar.jrc.ec.europa.eu/overview.php?v=42, Global emissions EDGARv4.2.

Giwa, S. O. (2014). Baseline Black Carbon Emission Inventory for Gas Flaring in the Niger Delta Region of Nigeria. LAP LAMBERT Academic Publishing, Saarbruken, Germany.

Houghton, J. T.; Y. Ding; D. J. Griggs; M. Noguer; P. J. V. D. Linder; X. Dai; K. Maskell and C. A. Johnson. (2001). Climate Change 2001: The Scientific Basis. Cambridge University Press, United Kingdom.

IPCC (Intergovernmental Panel on Climate), (1996). Climate change 1995: The science of climate change. Cambridge University Press, United Kingdom.

IPCC (Intergovernmental Panel on Climate), (2007). IPCC adapts major assessment of climate change science.
Available online at: www.ipcc.cn /press/prwg2feb07.html. Accessed on February 4, 2016.

IPCC (Intergovernmental Panel on Climate), (2006). IPCC Guidelines for National Greenhouse Gas Inventories, Volume 1: General Guidance and Reporting. IPCC, Geneva, Switzerland.

Lu, Y.; Z. Huang and T. Zhang. (2013). Method and Case Study of Quantitative Uncertainty Analysis in Building Energy Consumption Inventories. Energy and Buildings, 57: 193-198.

Ndoke, P. N. and Jimoh, O. D. (2005). Impact of Traffic Emission on Air Quality in a Developing City of Nigeria. AU Journal of Technology 8(4), 222-227.

NNPC (Nigerian National Petroleum Corporation), 1997. Annual Statistical Bulletin. Corporate Planning and Development Division (CPDD). January-December 1997, 1998, 2008 - 2014.

Nigeria's Second National Communication under the United Nations Framework Convention on Climate Change, 2014. Available online at: www.unfccc.int/resource/docs/natc/nganc2.pdf. Accessed on January 11, 2016.

Odjugo, P. A. O. (2001). Global Warming and Food Production: A Global and Regional Analysis. African Journal of Environmental Studies, 2 (2): 85-91.

Odjugo, P. A. O. and Ikhuoria, A. I. (2003). The Impact of Climate Change and Anthropogenic Factors on Desertification in the Semi-arid Region of Nigeria. Global Journal of Environmental Science, 2(2): 118-126.

Odjugo, P. A. O. (2009). Quantifying the Cost of Climate Change Impact in Nigeria: Emphasis on Wind and Rainstorms. Journal of Human Ecology, 28 (2): 93-101.

OECD/ITF, (1999). Reducing Transport Greenhouse Gas Emissions. Available online at: www.internationaltransportforum.org/Pub/pdf/10GHGTrends .pdf. Accessed on January 4, 2016.

US National Oceanic Atmospheric Administration. http://cdiac.esd.ornl.gov/ftp/trends/emissions/ngr.dat (visited last on $08 / 04 / 17$ ).

USEIA (United States Energy Information Administration). Carbon dioxide emissions data on fuel combustion for Nigeria (Personally obtained)

World Bank (2016). World development indicators. Nigeria. http://data.worldbank.org/country/nigeria. 